\title{
SKRINING DAN IDENTIFIKASI BAKTERI PEMBENTUK HISTAMIN YANG DIISOLASI DARI TUNA, TONGKOL, DAN CAKALANG SEGAR DI WILAYAH JAWA BARAT, DKI JAKARTA, DAN BANTEN
}

\section{Screening and Identification of Histamine Producing Bacteria Isolated from Fresh Tuna and Tuna-like from West Java, DKI Jakarta, and Banten Areas}

\author{
Novalia Rachmawati* dan Radestya Triwibowo \\ Balai Besar Riset Pengolahan Produk dan Bioteknologi Kelautan dan Perikanan, \\ JI. KS Tubun, Petamburan VI, Jakarta Pusat, DKI Jakarta, 10260, Indonesia \\ *Korespondensi penulis : novalia.rachmawati@kkp.go.id \\ Diterima: 27 April 2021; Direvisi: 10 Agustus 2021; Disetujui: 12 Oktober 2021
}

\begin{abstract}
ABSTRAK
Tuna, tongkol, cakalang (TTC) merupakan komoditas perikanan bernilai ekonomis penting yang disukai oleh banyak konsumen di Indonesia. Namun demikian, distribusi, penanganan, dan pengolahan komoditas ini masih banyak mengalami kendala, di antaranya kontaminasi bakteri pembentuk histamin (BPH) yang dapat menyebabkan akumulasi histamin dan menimbulkan kerugian kesehatan pada konsumen. Penelitian ini bertujuan untuk mengidentifikasi BPH dari komoditas TTC segar yang dijual di pasar domestik, mengevaluasi profilnya, serta mengkarakterisasi kemampuan BPH tersebut dalam menghasilkan histamin. Sebanyak 93 sampel TTC diperoleh dari TPI, pasar tradisional, dan pasar modern di wilayah Jawa Barat, DKI Jakarta, dan Banten. Dari 318 isolat presumtif BPH yang ditemukan, sebanyak 59 isolat (19\%) terkonfirmasi positif gen hdc dan di antaranya sebanyak 43 isolat dikategorikan sebagai BPH prolifik. Hasil sekuensing 16S rDNA menunjukkan sebanyak 30 dari 43 isolat BPH prolifik $(69,8 \%)$ adalah Morganella morganii. Selain M. morganii, isolat lain yang ditemukan dari semua jenis ikan yang diamati adalah Photobacterium damselae (6,9\%), keduanya merupakan BPH mesofilik. Isolat mesofilik lain yang teridentifikasi dari sampel TTC berasal dari genus Klebsiella (4,7\%), Proteus (4,7\%), Raoultella (4,7\%), Shewanella (2,3\%), dan Vibrio $(6,9 \%)$. Keberadaan BPH prolifik ini mengindikasikan adanya potensi akumulasi histamin pada produk akhir TTC apabila dalam penanganan dan pengolahannya tidak menerapkan sistem rantai dingin dengan benar.
\end{abstract}

KATA KUNCI : bakteri pembentuk histamin, tuna, tongkol, cakalang, pasar domestik

\section{ABSTRACT}

Tuna and tuna-like fish are economically important and popular amongst Indonesian consumers. However, the distribution, handling, and processing of these commodities are still facing many problems, including contamination of histamine producing bacteria (HPB) which may lead to histamine accumulation and cause human adverse health effects. This study aimed to identify HPB from fresh tuna and tuna-like fish sold in domestic markets in Indonesia, evaluate their profile, and characterize their ability to produce histamine. A number of 93 fish samples were obtained from fish landing, traditional and modern fish markets in West Java, DKI Jakarta, and Banten. Of 318 presumptive HPB identified from the sample, 59 isolates (19\%) were confirmed as hdc-gene positive with 43 isolates were categorized as prolific HPB. Bacterial identification with $16 S$ rDNA sequencing identified 30 out of 43 (69.8\%) prolific HPB as Morganella morganii. Besides M. morganii, another mesophilic HPB identified from all different type of fish was Photobacterium damselae $(6.9 \%)$, while the remaining mesophilic HPB were identified from genus Klebsiella (4.7\%), Proteus (4.7\%), Raoultella (4.7\%), Shewanella (2.3\%), and Vibrio $(6.9 \%)$. The presence of prolific HPB in the samples suggested that histamine accumulation in the final product is possible if cold-chain system is not properly applied during fish handling and processing.

KEYWORDS: histamine producing bacteria, tuna and tuna like species, domestic markets 


\section{PENDAHULUAN}

TTC (tuna, tongkol, cakalang) tergolong sebagai komoditas perikanan bernilai ekonomis penting dari sektor perikanan tangkap di Indonesia (KKP, 2016). Total produksi perikanan tangkap Indonesia pada tahun 2018 sebesar 7,2 juta ton dengan produksi tuna, tongkol, dan cakalang (berdasarkan perhitungan angka sementara) berturut-turut 306 ribu, 492 ribu, dan 488 ribu ton (Pusdatin KKP, 2018). Indonesia telah menjadi salah satu negara yang berkontribusi besar pada perdagangan TTC dunia dengan volume ekspor pada tahun 2017 mencapai 203 ribu ton senilai 678 juta US dollar (Widria, 2018). Di samping itu, TTC dan olahannya juga merupakan salah satu komoditas favorit yang banyak dikonsumsi masyarakat Indonesia (Virgantari, Daryanto, Harianto, \& Kuntjoro, 2011) terutama di Maluku dan Sulawesi. Komoditas TTC bersama dengan komoditas ikan lainnya berperan dalam peningkatkan konsumsi ikan nasional di Indonesia.

Permasalahan mengenai tingkat mutu, kualitas, dan keamanan produk perikanan yang tidak memenuhi standar dan kontinuitas stok ikan di pasar (Wuryandani \& Meilani, 2011) masih sering dihadapi, termasuk pada ikan TTC untuk pasar domestik. Kasus keracunan pangan akibat mengkonsumsi TTC dilaporkan terjadi hampir setiap tahun dari berbagai wilayah di Indonesia. Beberapa kejadian luar biasa (KLB) tersebut menyebabkan lebih dari 300 orang di Jember (Supriadi, 2020), 50 orang di Pasaman (Antara, 2020), 53 orang di Pemalang (Chendaki, 2020; Suryono, 2020), dan 19 orang di Batang (Raharjo, 2020) mengalami keracunan. Salah satu penyebab keracunan pangan akibat konsumsi ikan adalah tingginya kadar histamin. Histamin merupakan hasil proses dekarboksilasi histidin pada daging ikan dengan bantuan enzim L-histidin dekarboksilase dari bakteri pembentuk histamin/BPH (FAO \& WHO, 2012). Histamin memiliki ketahanan terhadap perlakuan suhu seperti pembekuan, pengeringan, pemanasan, dan lingkungan ber-pH rendah (ICMSF, 2005; USFDA, 2011; Visciano, Schirone, Tofalo, \& Suzzi, 2012). Ikan dari golongan Scombroidae (termasuk tuna, tongkol, cakalang) serta ikan-ikan dari golongan lain seperti Carangidae (kue, layang, tengkek) dan Clupeidae (lemuru, sarden, tembang) secara alami memiliki kandungan histidin yang lebih tinggi dibanding ikan dari golongan lainnya (Visciano et al., 2012; Visciano, Schirone, Tofalo, \& Suzzi, 2014).

Penanganan dan pengolahan TTC yang dilakukan secara tidak higienis serta tidak mengikuti kaidah sistem rantai dingin dapat memicu pertumbuhan $\mathrm{BPH}$ dan pembentukan histamin yang berlebihan pada daging ikan (Rachmawati, 2019). Meskipun BPH merupakan bakteri yang tidak tahan panas atau tidak dapat tumbuh pada suhu beku, namun histamin yang sudah terbentuk pada daging ikan akan tetap ada selama proses pembekuan, pengolahan, atau pemasakan. Akibatnya, dapat menimbulkan risiko keracunan makanan pada konsumen (FAO \& WHO, 2012; Lehane \& Olley, 2000). Oleh karena itu, upaya untuk mencegah atau meminimalisir terbentuknya histamin perlu dilakukan sejak awal, seperti penerapan rantai dingin sejak ikan didaratkan hingga penanganan, pengolahan, penyimpanan, dan pendistribusian. Langkah ini dilakukan untuk menghambat pertumbuhan BPH pada ikan sehingga akitivitas dekarboksilase histidin dapat ditekan.

Isolasi BPH diperlukan sebagai upaya untuk mengetahui jenis $\mathrm{BPH}$ dominan yang mengkontaminasi produk perikanan di Indonesia, serta mempelajari kemampuan isolat tersebut untuk beradaptasi dan menghasilkan histamin pada kondisi penanganan dan pengolahan produk perikanan yang berbeda. Hal ini merupakan salah satu faktor penting yang diperlukan dalam studi atau kajian risiko histamin pada produk perikanan. Beberapa studi untuk mengetahui jenis BPH yang berperan dalam pembentukan histamin pada produk perikanan di Indonesia pernah dilakukan pada ikan olahan seperti pindang (Fatuni, Suwandi, \& Jacoeb, 2014; Rachmawati, 2019), kembung peda (Indriati, Rispayeni, \& Heruwati, 2006), serta beberapa komoditas TTC untuk ekspor yang telah mengalami proses penyimpanan pada suhu yang berbeda (Nurilmala et al., 2020; Wahyuni, 2011). Sementara itu, informasi terkait BPH pada TTC segar untuk konsumsi domestik masih sangat terbatas. Salah satu informasi yang tersedia merupakan hasil studi pada tuna mata besar yang diperoleh dari Muara Baru (Wodi, 2015). Oleh karena itu, penelitian ini bertujuan untuk mengisolasi dan mengidentifikasi jenis BPH pada ikan TTC segar yang berasal dari TPI maupun pasar domestik, khususnya di wilayah Jawa Barat, DKI Jakarta dan Banten. Penelitian ini juga bertujuan untuk mengevaluasi profil BPH dan mengetahui kemampuannya dalam menghasilkan histamin. Pemilihan lokasi didasarkan pada tingginya nilai konsumsi ikan per kapita serta volume ikan TTC yang didaratkan di wilayah tersebut.

\section{BAHAN DAN METODE}

\section{Bahan}

Sebanyak 93 individu ikan segar yang terdiri atas 32 ekor tuna, 36 ekor tongkol dan 25 ekor cakalang diperoleh dari TPI, pasar ikan/pasar tradisional, pasar 
modern, dan retail di wilayah DKI Jakarta, Jawa Barat, dan Banten pada tahun 2020 (Tabel 1). Pengambilan sampel dilakukan secara acak berdasarkan ketersediaan ikan di lokasi. Suhu ikan pada saat pengambilan sampel diukur dan didokumentasikan. Selanjutnya, sampel ikan ditransportasikan ke laboratorium dengan mempertahankan suhunya kurang dari $4^{\circ} \mathrm{C}$ dengan cara penggantian dan penambahan es curai secara berkala dengan perbandingan berat ikan:es $=1: 3$.

\section{Metode}

\section{Skrining dan isolasi BPH}

Skrining dan isolasi BPH dilakukan secara bertahap berdasarkan metode dari Torido et al. (2014). Sebanyak $5 \mathrm{gr}$ edible portion sampel diambil dari daging ikan yang telah dikomposit dan diinokulasi ke dalam $45 \mathrm{ml}$ histidine broth (HB). Tahap pengayaan ini dilakukan selama $24-36$ jam pada suhu $30^{\circ} \mathrm{C}$. Kultur yang dihasilkan selanjutnya dilakukan pengayaan kembali pada media HB baru dan diinkubasi kembali pada kondisi yang sama.

Tahap berikutnya adalah langkah untuk mendapatkan koloni tipikal BPH. Sebanyak satu ose kultur dari media HB yang baru tersebut digoreskan ke permukaan media agar Niven pada cawan petri (Niven, Jeffrey, \& Corlett, 1981), dan diinkubasi selama 24-36 jam pada suhu $30^{\circ} \mathrm{C}$. Pengamatan koloni presumtif/tipikal yang tumbuh pada cawan petri tersebut dilakukan secara visual terhadap koloni yang berwarna ungu kebiruan dengan atau tanpa halo di sekitar koloninya. Pada setiap sampel, sebanyak 35 koloni tipikal yang tumbuh pada media agar Niven diambil dan ditumbuhkan (digoreskan) kembali pada media tryptone soy agar (TSA) (Oxoid, Inggris) yang ditambahkan $2 \% \mathrm{NaCl}$ (Merck, US). Koloni tunggal akan diperoleh pada cawan petri setelah media TSA diinkubasi pada suhu $30^{\circ} \mathrm{C}$ selama $24-36$ jam. Koloni tunggal yang diperoleh selanjutnya disimpan dalam 500 $\mu$ I Tris-EDTA (TE) buffer dan kemudian disimpan pada suhu $-20^{\circ} \mathrm{C}$ untuk digunakan pada tahap konfirmasi secara molekuler.

\section{Konfirmasi BPH secara molekuler}

Tahap konfirmasi BPH selanjutnya dilakukan secara molekuler dengan gen target $h d c$ (gen yang mengekspresikan produksi l-histidin dekarboksilasi). DNA dari isolat tunggal yang diperoleh dari tahap sebelumnya (Sub bab skrining dan isolasi BPH) diekstraksi menggunakan Presto ${ }^{\mathrm{TM}}$ Mini gDNA (Geneaid, Taiwan). Pasangan primer yang digunakan adalah $h d c-F$ (5'-TCH ATY ARY AAC TGY GGT GAC TGG RG-3') dan hdc-R (5'-CCC ACA KCA TBA RWG GDG TRT GRC C-3') yang mentargetkan gen hdc dengan ukuran 709-bp (Takahashi, Kimura, Yoshikawa, \& Fujii, 2003). Untuk kontrol internal digunakan pasangan primer universal $16 s-F$ (CCTACG GGAGGCAGCAGT) dan 16s-R (CGTTTACGG CGT GGA CTA C) dengan target gen 16S rDNA berukuran 475-bp (Chiang et al., 2006). Sebanyak $40 \mu \mathrm{l}$ campuran reaksi yang terdiri atas $20 \mu \mathrm{l} \mathrm{MyTaq}{ }^{\mathrm{TM}} \mathrm{HS}$ Mix (Bioline, AU), $2 \mu \mathrm{l}$ masing-masing primer $(10 \mu \mathrm{M}$ $h d c-F$ dan $h d c-R ; 1 \mu \mathrm{M} 16 s-F$ dan $16 s-R), 2,5-5 \mu \mathrm{l}$

Tabel 1. Jumlah sampel yang diambil di tiap lokasi

Table 1. The number of samples collected from each location

\begin{tabular}{lcccc}
\hline \multirow{2}{*}{$\begin{array}{l}\text { Lokasi Pengambilan Sampel/ } \\
\text { Sampling Location }\end{array}$} & \multicolumn{3}{c}{ Jenis Ikan/Fish Species } & Jumlah Sampel/ \\
\cline { 2 - 4 } & $\begin{array}{c}\text { Tuna/ } \\
\text { Tuna }\end{array}$ & $\begin{array}{c}\text { Tongkol/ } \\
\text { Little tuna }\end{array}$ & $\begin{array}{c}\text { Cakalang/ } \\
\text { Skipjack }\end{array}$ & Total Sample \\
\hline TPI/ Fish landing site & 11 & 5 & 11 & 27 \\
Pasar ikan tradisional/ & 3 & 8 & 0 & 11 \\
$\begin{array}{l}\text { Traditional fish market } \\
\text { Pasar modern/ }\end{array}$ & 12 & 6 & 11 & 29 \\
$\begin{array}{l}\text { Modern fish market } \\
\text { Pengecer/Retailer }\end{array}$ & 6 & 17 & 3 & 26 \\
\hline Total & & & & 93 \\
\hline
\end{tabular}

Catatan/Notes:

1) Sampel beku terdiri atas 1 tuna dari pasar ikan tradisional, 2 tuna dari pasar modern, 4 tuna dan 1 cakalang dari pengecer/Frozen samples were 1 tuna from traditional fish market, 2 tunas from modern market, 4 tunas, and 1 skipjack from retailer.

2) Sampel lain diperoleh dalam kondisi segar/The remaining fish were obtained in fresh. 
cetakan DNA dan air bebas nuclease, digunakan untuk reaksi molekuler. Kondisi thermal cycler diatur sebagai berikut, denaturasi awal $\left(94^{\circ} \mathrm{C}\right.$ selama 4 menit), 35 siklus amplifikasi $\left(4^{\circ} \mathrm{C}\right.$ selama 1 menit, $58^{\circ} \mathrm{C}$ selama 1 menit, dan $72^{\circ} \mathrm{C}$ selama 1 menit), serta perpanjangan akhir $\left(72^{\circ} \mathrm{C}\right.$ selama 4 menit). Produk PCR selanjutnya dielektroforesis menggunakan 1,5\% gel agarose dalam $1 x$ Tris-Borate EDTA (TBE) dengan kondisi elektroforesis pada $90 \mathrm{~V}$ selama $50 \mathrm{~min}$. Hasil elektroforesis divisualisasi menggunakan UV transilluminator (Biometra, Jerman).

\section{Konfirmasi kemampuan BPH dalam menghasilkan histamin}

Isolat yang terkonfirmasi positif gen hdc selanjutnya diuji kemampuannya dalam menghasilkan histamin. Kultur tunggal yang diperoleh dari TSA $(+2 \% \mathrm{NaCl})$ (sub bab skrining dan isolasi $\mathrm{BPH}$ ) ditumbuhkan dalam media HB selama $24-36$ jam pada suhu $30^{\circ} \mathrm{C}$. Kultur kemudian disentrifuse kecepatan $10.000 \mathrm{xg}$ selama 2 menit. Sebanyak 1-2 ml supernatan diambil dan disaring menggunakan filter cellulose acetate berdiameter $13 \mathrm{~mm}$ dengan diameter pori 0,22 $\mu \mathrm{m}$. Jika diperlukan, pengenceran bertingkat ekstrak kultur dilakukan menggunakan double distilled water.

Pengujian kandungan histamin dilakukan

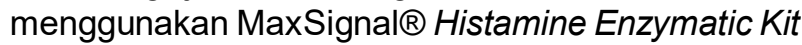
(Perkin Elmer, US) dengan mengikuti petunjuk penggunaan kit. Kurva kalibrasi diperoleh berdasarkan pembacaan standar histamin dengan konsentrasi 0; 1; 2; 4; 8 dan 12 ppm pada panjang gelombang 450 $\mathrm{nm}$. Konsentrasi histamin pada sampel dihitung menggunakan persamaan non-linear 4-parameter logistic/4PL (Cox et al., 2004).

\section{Identifikasi BPH dengan sekuensing}

Isolat yang ditumbuhkan pada media HB dan mampu menghasilkan histamin pada konsentrasi $>125$ ppm, dikategorikan sebagai BPH (Bjornsdottir, Bolton, McClellan-Green, Jaykus, \& Green, 2009). Isolat ini selanjutnya diidentifikasi dengan teknik sekuensing yang mentargetkan gen $16 \mathrm{~S}$ ribosomal DNA (16S rDNA). Pasangan primer yang digunakan adalah 27F (5'-AGA GTT TGA TCC TGG CTCAG-3') dan 1492R (5'-TAC GGY TAC CTT GTT ACG ACT T3') (Weisburg, Barns, Pelletier, \& Lane, 1991) dengan kondisi thermal cycleryang diawali dengan denaturasi pada $95^{\circ} \mathrm{C}$ selama 2 menit dan diikuti 30 siklus amplifikasi $\left(95^{\circ} \mathrm{C}\right.$ selama 1,5 menit, $55^{\circ} \mathrm{C}$ selama 1,5 menit, dan $72^{\circ} \mathrm{C}$ selama 1,5 menit) serta perpanjangan akhir pada $72^{\circ} \mathrm{C}$ selama 1,5 menit (Bjornsdottir-Butler, Jones, Benner, \& Burkhardt III, 2011). Setiap reaksi PCR dilakukan dengan volume total $40 \mu$ yang terdiri atas $20 \mu \mathrm{l} \mathrm{MyTaq}{ }^{\mathrm{TM}}$ HS Mix (Bioline, AU), 1-2 $\mu$ l primer
27- $F$ dan 1492- $R$ (dengan konsentrasi masing-masing primer $10 \mu \mathrm{M}), 2,5 \mu$ l cetakan DNA dan air bebas nuclease. Sebanyak $5 \mu$ dari masing-masing produk hasil reaksi PCR dikonfirmasi dengan gel elektroforesis dan sebanyak $20 \mu$ sisanya digunakan untuk sekuensing yang dilakukan menggunakan jasa sekuensing komersial di $1^{\text {st }}$ BASE (Singapura).

Sekuens atau urutan basa yang dihasilkan kemudian divisualisasi menggunakan Sequence Scanner 2 untuk memperbaiki area yang beresolusi rendah. Sekuens yang sama, sekuens type strain dan sekuens takson outgroup diperoleh dari database nukleotida NCBI (Nucleotide, 1998). Alignment sekuens dan analisa filogenetik dilakukan menggunakan perangkat lunak Molecular Evolutionary Genetics Analysis (MEGA) versi 6.0 dengan metode Neighbour Joining dengan 1.000 ulangan bootstrap (Tamura, Stecher, Peterson, Filipski, \& Kumar, 2013).

\section{HASIL DAN PEMBAHASAN}

\section{Isolasi dan Karakterisasi BPH dari Sampel Ikan Tuna, Tongkol, dan Cakalang}

Pengamatan secara visual terhadap koloni yang tumbuh di media agar Niven menunjukkan bahwa koloni tipikal (yang selanjutnya disebut sebagai isolat presumtif) diidentifikasi sebagai koloni yang berwarna ungu keabu-abuan dengan atau tanpa halo (perubahan warna media di sekitar koloni). Sebanyak 318 isolat presumtif BPH ditemukan dari seluruh sampel ikan (Tabel 2). Dari seluruh isolat presumtif tersebut, sebanyak 59 isolat (19\%) terkonfirmasi positif gen hdc berdasarkan analisa secara molekuler. Tingginya false positive yang teramati pada media agar Niven salah satunya disebabkan oleh terbentuknya hasil metabolisme selain histamin. Hal ini dapat meningkatkan $\mathrm{pH}$ media dan teramati sebagai perubahan warna yang menyerupai isolat $\mathrm{BPH}$ pada media agar (Björnsdóttir-Butler, Bolton, Jaykus, McClellan-Green, \& Green, 2010; Kim et al., 2001).

Komposisi total isolat yang terkonfirmasi positif hdc pada sampel ikan tuna, tongkol dan cakalang berturut-turut 18,$0 ; 18,1$; dan $20 \%$ dari total isolat presumtif yang terisolasi dari media Niven. Hasil pengukuran histamin pada media HB (setelah diinkubasi pada suhu $30^{\circ} \mathrm{C}$ selama $24-36$ jam) yang diinokulasi masing-masing dengan 59 isolat positif $h d c$ menunjukkan sebanyak 43 isolat terkonfirmasi sebagai BPH. Bakteri dapat dikategorikan sebagai BPH apabila mampu menghasilkan histamin sebanyak >1.000 ppm (high producer) atau 126-500 ppm (low producer) setelah ditumbuhkan pada media HB dan dikategorikan sebagai non producer (bukan 
Tabel 2. Jumlah dan prosentase BPH hasil skrining dari sampel TTC per jenis ikan Table 2. Screening results of histamine producing bacteria (HPB) from tuna and tuna-like fish

\begin{tabular}{lcccc}
\hline $\begin{array}{c}\text { Jenis Ikan/ } \\
\text { Fish Type }\end{array}$ & $\begin{array}{c}\sum \text { Sampel Ikan/ } \\
\sum \text { Fish Samples }\end{array}$ & $\begin{array}{c}\sum \text { Koloni } \\
\text { Presumtif BPH/ } \\
\sum \text { Presumptive } \\
\text { HPB }\end{array}$ & $\begin{array}{c}\sum \text { Isolat Positif Gen } \\
\text { hdc (\%) } 1 / \sum \text { hdc } \\
\text { Positive Isolate (\%) }{ }^{1}\end{array}$ & $\begin{array}{c}\sum \text { Isolat BPH (\%) }{ }^{2} \text { I } \\
\text { P HPB Isolate (\%) }\end{array}$ \\
\hline Tuna/Tuna & 32 & 100 & $18(18.0)$ & $15(83.3)$ \\
Tongkol/Little tuna & 36 & 138 & $25(18.1)$ & $19(76.0)$ \\
Cakalang/Skipjack & 25 & 80 & $16(20.0)$ & $9(56.3)$ \\
\hline Total & 93 & 318 & $59(19.0)$ & $43(72.9)$ \\
\hline
\end{tabular}

Keterangan/Notes:

1 Prosentase isolat positif $h d c$ dihitung dari total koloni presumptif untuk setiap jenis ikan/Percentages of hdcpositive isolates were calculated from total number of presumptive colonies for each fish

2 Prosentase isolat BPH dihitung dari total isolat positif hdc untuk setiap jenis ikan/Percentages of HPB isolates were calculated from total hdc-positive isolate for each fish

BPH) jika menghasilkan histamin $<125$ ppm histamin (Bjornsdottir et al., 2009).

Prosentase isolat positif $h d c$ yang terkonfirmasi sebagai BPH untuk tuna, tongkol dan cakalang berturut-turut sebesar 83,$3 ; 76,0$ dan $56,3 \%$. Dalam penelitian ini, seluruh BPH mampu menghasilkan histamin $>1.000$ ppm sehingga dapat dikategorikan sebagai high histamine producer atau BPH prolifik. Hal ini menunjukkan bahwa tahapan konfirmasi secara molekuler sangat diperlukan dalam identifikasi BPH untuk meminimalisir kemungkinan false positive yang tinggi pada isolat presumtif yang tumbuh di media agar Niven. Sebagai contoh, pada sampel ikan tuna menunjukkan sebanyak $15 \%$ atau 15 isolat dari total 100 isolat presumtif (pada media agar Niven) yang terkonfirmasi sebagai BPH. Namun bila dibandingkan dengan tahapan konfirmasi secara molekuler (analisa gen $h d c)$, maka 15 isolat $(83,33 \%)$ dari total 18 isolat terkonfirmasi sebagai BPH.

Beberapa studi menunjukkan bahwa pembentukan histamin oleh BPH terjadi pada fase pertumbuhan eksponensial. Sebagai contoh adalah produksi histamin oleh $M$. morganii dengan hasil tertinggi terjadi pada pertengahan fase exponensial (Kim, 2001; Omura, Price, \& Olcott, 1978; Yoshinaga \& Frank, 1982). Jenis bakteri lain seperti Enterobacter aerogenes dan Tetragenococcus muriaticus menghasilkan histamin dengan kadar tertinggi pada fase eksponensial akhir (Kimura, Konagaya, \& Fujii, 2001; Rachmawati, 2019; Takahashi et al., 2003). Demikian pula hasil yang diperoleh dari penelitian ini, isolat positif $h d c$ menghasilkan histamin $>125 \mathrm{ppm}$ pada fase eksponensial dengan kepadatan sel $10^{7}$ $10^{8} \mathrm{CFU} / \mathrm{ml}$ (data tidak ditunjukkan). Faktor lain yang mempengaruhi pembentukan histamin adalah jumlah histidin bebas dalam daging ikan. Pada ikan tuna, histidin bebas dalam daging berkisar antara 10.00020.000 ppm (Emborg, Dalgaard, Kjølby, Sørensen, \& Larsen, 2008; Fletcher, Summers, Winchester, \& Wong, 1995).

\section{Hasil Identifikasi BPH dengan Sekuensing}

Hasil identifikasi isolat BPH dari sampel TTC yang diperoleh berdasarkan analisa sekuensing dan filogenetik (Gambar 1) secara keseluruhan menunjukkan sebanyak $69,8 \%$ isolat $(30 / 43)$ teridentifikasi sebagai Morganella morganii (Tabel 3). Isolat ini diisolasi dari ketiga jenis ikan, yaitu tuna, tongkol, dan cakalang. M. morganii merupakan salah satu bakteri yang paling sering menjadi penyebab pembentukan histamin pada ikan, selain bakteri Gram negatif lain dari golongan Enterobacteriaceae, yaitu: Raoultella planticola, Raoultella ornithinolytica, Hafnia alvei, Klebsiella pneumonia, Citrobacter freundii, E. aerogenes, dan Proteus vulgaris (Björnsdóttir-Butler et al., 2010; Lehane \& Olley, 2000; Visciano, Schirone, \& Paparella, 2020; Visciano et al., 2012). M. morganii yang diisolasi dari sampel produk perikanan dari beberapa retailer di Jepang mampu menghasilkan histamin hingga lebih dari $1.000 \mathrm{mg} /$ $\mathrm{kg}$ setelah ditumbuhkan pada media histidine broth selama 24 jam pada suhu $30^{\circ} \mathrm{C}$ (Torido et al., 2014). Keterlibatan spesies $M$. morganii sebagai penyebab kasus keracunan histamin setelah mengkonsumsi produk perikanan telah dilaporkan sejak tahun 1980an (Klausen \& Huss, 1987; Taylor, 1986) dan hingga saat ini masih banyak laporan kasus keracunan histamin yang disebabkan oleh kontaminasi bakteri ini (Hwang et al., 2019; Lee, Huang, Lin, Lin, \& Tsai, 2012). Di Indonesia, jenis bakteri ini juga ditemukan 

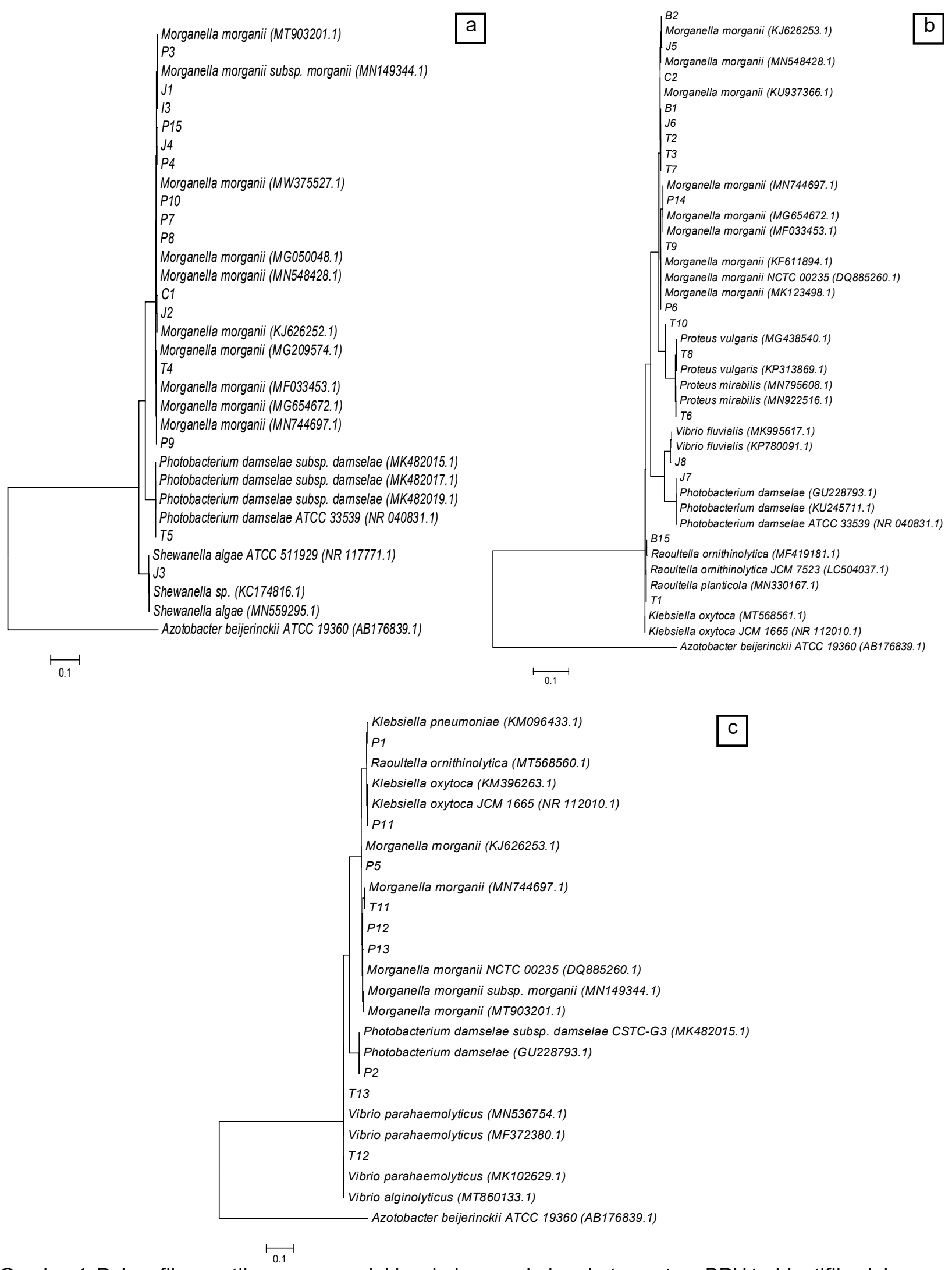

Gambar 1. Pohon filogenetik yang menunjukkan hubungan kekerabatan antara BPH teridentifikasi dengan type strain dan outgroup taxa dari sampel (a) tuna; (b) tongkol; dan (c) cakalang.

Figure 1. Phylogenetic tree showing the relationship between identified HPB with type strains and outgroup taxa, from (a) tuna; (b) little tuna; and (c) skipjack. 
Tabel 3. Hasil identifikasi isolat BPH dengan metode PCR sekuensing

Table 3. Identified HPB isolate based on PCR sequencing

\begin{tabular}{lcccc}
\hline \multirow{2}{*}{$\begin{array}{l}\text { Spesies BPH Teridentifikasi// } \\
\text { Identified HPB }\end{array}$} & \multicolumn{2}{c}{ Jumlah Isolat BPH/Number of HPB } & \\
\cline { 2 - 4 } & $\begin{array}{c}\text { Tunal } \\
\text { Tuna }\end{array}$ & $\begin{array}{c}\text { Tongkol/ } \\
\text { Little tuna }\end{array}$ & $\begin{array}{c}\text { Cakalang/ } \\
\text { Skipjack }\end{array}$ & \\
\hline Klebsiella oxytoca & - & - & 1 & 1 \\
K. pneumoniae & - & - & 1 & 1 \\
Morganella morganii & 13 & 13 & 4 & 30 \\
Photobacterium damselae & 1 & 1 & 1 & 3 \\
Proteus mirabilis & - & 1 & - & 1 \\
P. vulgaris & - & 1 & - & 1 \\
Raoultella planticola & - & 1 & - & 1 \\
R. ornitholytica & - & 1 & - & 1 \\
Shewanella sp. & 1 & - & - & 1 \\
Vibrio fluvialis & - & 1 & - & 1 \\
V. parahaemolyticus & - & - & 9 & 2 \\
\hline Total & 15 & 19 & & 43 \\
\hline
\end{tabular}

baik pada produk perikanan segar (Nurilmala et al., 2020) maupun olahan seperti pindang (Fatuni et al., 2014; Rachmawati, 2019).

Selain M. morganii, BPH lain yang teridentifikasi dari ketiga jenis sampel ikan adalah Photobacterium damselae dengan jumlah 6,9\% (3/43) dari total isolat yang ditemukan. Bakteri ini ditemukan pada beragam jenis produk perikanan segar seperti bonito, tuna, makarel, sauri, todak, dan sardin (Torido et al., 2014) serta belanak (Trevisani, Mancusi, Cecchini, Costanza, \& Prearo, 2017) dengan produksi histamin lebih dari $1.000 \mathrm{mg} / \mathrm{kg}$. Seperti halnya M. morganii, bakteri ini tergolong sebagai bakteri mesofilik yang tumbuh optimum pada suhu $30-35^{\circ} \mathrm{C}$ di lingkungan dengan kadar garam 1-3\% (Bjornsdottir-Butler, Bowers, \& Benner, 2015). Meskipun laporan yang menunjukkan keterlibatan $P$. damselae dalam kasus keracunan histamin belum ada, namun dilihat dari kemampuan bakteri ini dalam menghasilkan histamin dalam kadar yang toksik, maka keberadaannya perlu mendapat perhatian karena ada kemungkinan akan menjadi penyebab kasus keracunan histamin di masa yang akan datang (Bjornsdottir-Butler et al., 2015; Kanki, Yoda, Tsukamoto, \& Baba, 2007; Torido et al., 2014). Keberadaan M. morganii dan $P$. damselae pada produk perikanan perlu mendapat perhatian khusus mengingat aktivitas dekarboksilasi dari kedua jenis bakteri ini masih bisa tetap berlangsung meskipun aktifitas mikrobanya sudah dinonaktifkan (Gardini, Özogul, Suzzi, Tabanelli, \& Özogul, 2016; Visciano et al., 2020).
Profil BPH yang teridentifikasi dari sampel TTC menunjukkan bahwa berdasarkan jenis dan jumlahnya, isolat BPH paling banyak ditemukan pada sampel ikan tongkol dibanding sampel ikan tuna dan cakalang (Gambar 2). Dari 7 genus yang teridentifikasi, sebanyak 5 genus ditemukan pada sampel tongkol, yaitu Vibrio, Raoutella, Proteus, Photobacterium, dan Morganella. Sedangkan pada sampel tuna dan cakalang, teridentifikasi masingmasing sebanyak 3 dan 4 genus. Keberadaan BPH pada produk perikanan dapat berasal dari alam maupun sebagai akibat dari kontaminasi setelah penangkapan. BPH seperti M. morganii, R. planticola dan $E$. aerogenes dapat ditemukan secara alami di saluran pencernaan, insang, maupun kulit ikan pada saat ikan ditangkap (Bjornsdottir et al., 2009; FAO \& WHO, 2012). Sementara itu, Photobacterium spp. diketahui sebagai mikrobiota alami sekaligus bakteri yang ditemukan sebagai akibat kontaminasi silang pada saat penanganan ikan (Torido et al., 2014).

Studi terdahulu menunjukkan bahwa sebagian besar BPH yang menjadi penyebab kasus keracunan histamin berasal dari golongan bakteri mesofilik (tumbuh optimum pada suhu $30-35^{\circ} \mathrm{C}$ dengan kadar garam 1-3\%). Hal ini mengindikasikan bahwa akumulasi histamin terjadi akibat kegagalan dalam menjaga sistem rantai dingin selama penanganan dan pengolahan produk perikanan (Lehane \& Olley, 2000; Torido et al., 2014). Untuk menghambat pembentukan histamin pada ikan dari jenis Scombridae, FAO telah menyarankan proses pendinginan pada suhu $\pm 4,4^{\circ} \mathrm{C}$ 


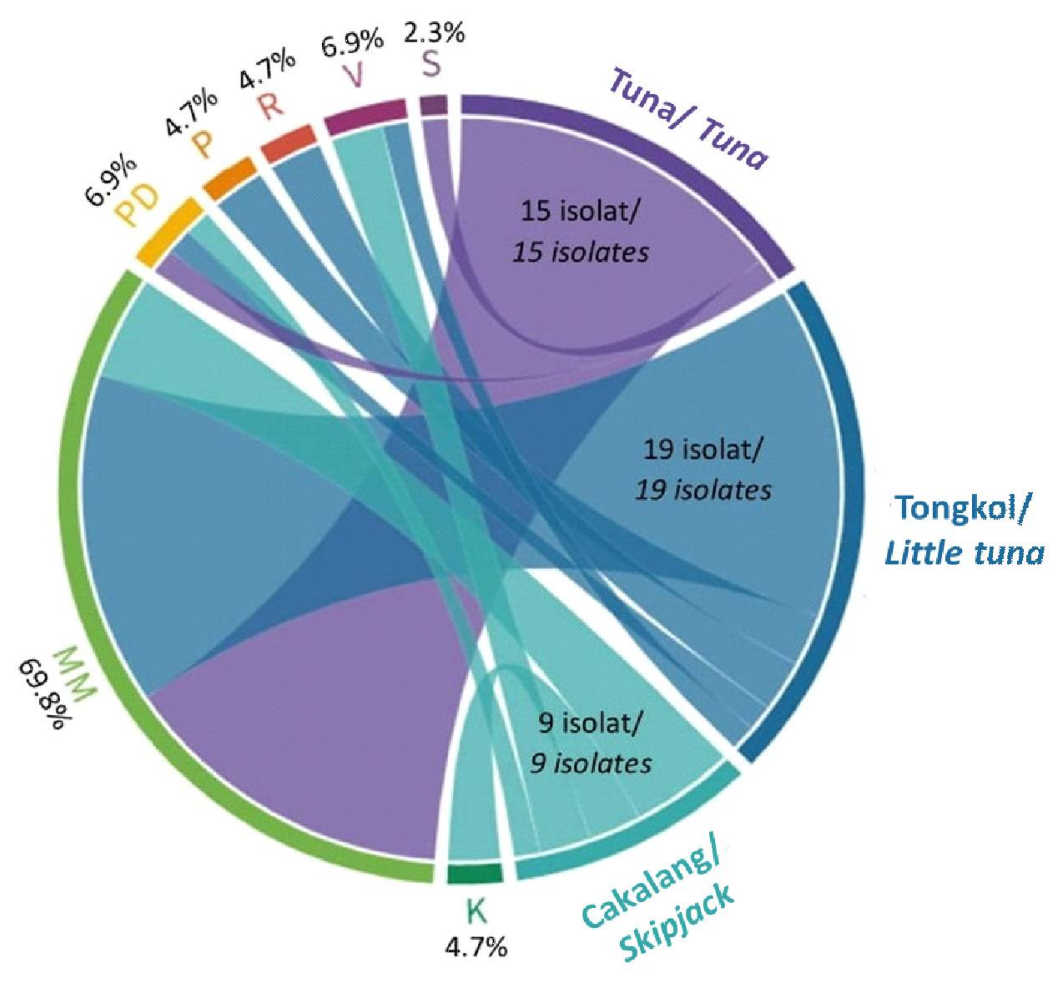

Keterangan/Notes:

S: Shewanella sp., V: Vibrio sp., R: Raoultella sp., P: Proteus sp., PD: Photobacterium damselae, MM: M. morganii, $\mathrm{K}$ : Klebsiella sp. Nilai dalam \% menunjukkan prosentase masing-masing isolat per total isolat yang teridentifikasi/

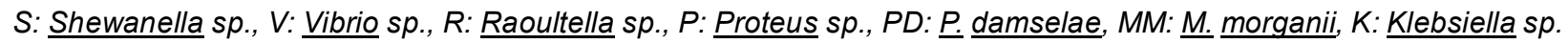
Values in \% represent the percentage of each isolate per total of the identified isolates.

Gambar 2. Profil BPH yang diisolasi dari sampel TTC.

Figure 2. HPB profile isolated from tuna and tuna-like sample.

segera setelah ikan ditangkap terutama untuk ikan di wilayah perairan bersuhu hangat (USFDA, 2011).

Sistem rantai dingin merupakan titik kritis penanganan dan pengolahan ikan di wilayah tropis, termasuk Indonesia, karena pada beberapa lokasi pendaratan ikan masih terdapat keterbatasan persediaan es. Data hasil pengukuran suhu ikan pada saat pengambilan sampel di lapangan (Gambar 3) menunjukkan adanya variasi dari $-2,8^{\circ} \mathrm{C}$ hingga $19,9^{\circ} \mathrm{C}$. Sampel ikan yang diambil dari pelabuhan, TPI atau pasar ikan yang letaknya tidak jauh dari TPI cenderung memiliki suhu yang lebih rendah (beku sampai $11,8^{\circ} \mathrm{C}$ ) daripada sampel dari pasar modern maupun retail atau supermarket (beku sampai $19,9^{\circ} \mathrm{C}$ ). Hasil observasi pada saat pengambilan sampel menunjukkan bahwa meskipun tingkat kebersihan dan penataan pasar modern secara umum lebih baik dibandingkan pasar tradisional maupun TPI, namun ketersediaan es di jenis pasar ini masih terbatas sehingga suhu ikan dapat mencapai $19,9^{\circ} \mathrm{C}$.
Dari keseluruhan sampel yang diambil, sebanyak 8 sampel ( 7 tuna dan 1 cakalang) diperoleh dalam bentuk beku dengan suhu berkisar antara -2,8 sampai $0,8^{\circ} \mathrm{C}$. Sampel tersebut diambil dari TPI, pasar modern dan retail. $\mathrm{BPH}$ ditemukan di 3 sampel beku dan teridentifikasi sebagai $M$. morganii dan $P$. damselae, keduanya merupakan BPH mesofilik. Selain dari golongan mesofilik, beberapa BPH prolifik merupakan bakteri psikrofilik yang mampu tumbuh pada suhu rendah $\left(0-5^{\circ} \mathrm{C}\right)$, seperti $P$. phosporeum dan $M$. psychrotolerans (Dalgaard, Madsen, Samieian, \& Emborg, 2006; Torido et al., 2014). Dalam penelitian ini tidak ditemukan isolat dari golongan psikrofilik, meskipun dari sampel yang diambil dalam bentuk beku. Hal ini dikarenakan suhu yang digunakan dalam prosedur isolasi $\left(30^{\circ} \mathrm{C}\right)$ tidak mendukung pertumbuhan bakteri psikrofilik tersebut. Beberapa BPH psikrofilik seperti M. psychrotolerans dan P. phosphoreum diketahui dapat menghasilkan histamin pada suhu rendah $\left(<2,5^{\circ} \mathrm{C}\right)$, namun demikian kasus keracunan 


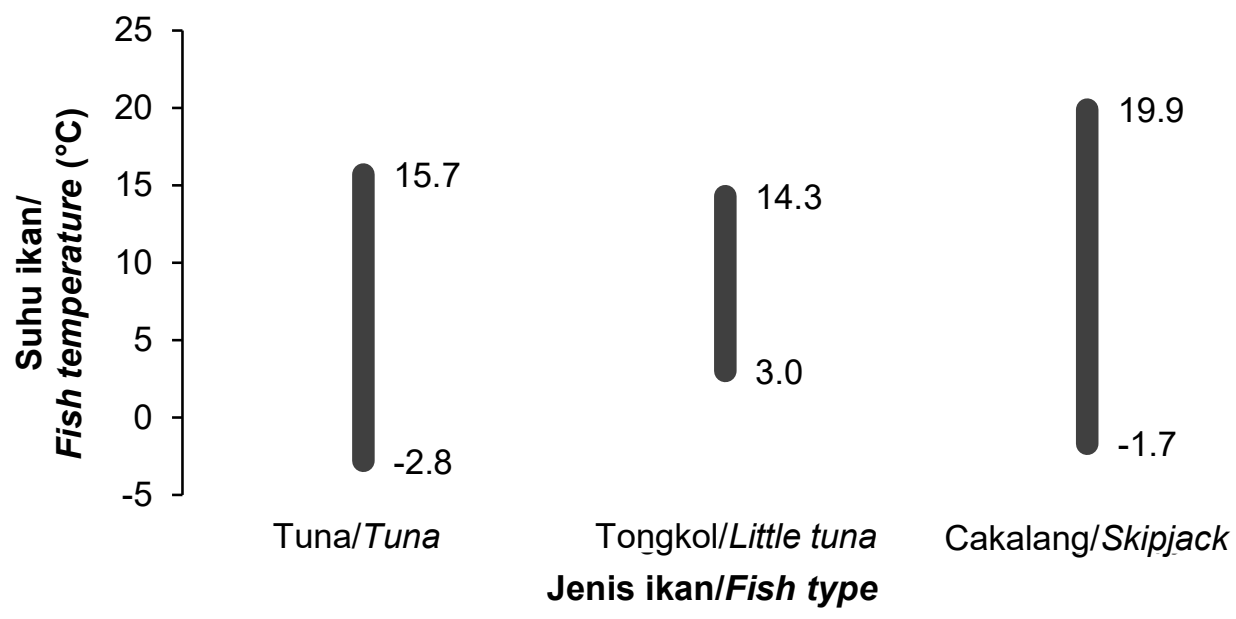

Gambar 3. Suhu ikan pada saat pengambilan di lapangan

Figure 3. Fish temperature during sample collection

pangan akibat histamin masih didominasi oleh BPH mesofilik sebagai mikroflora alami pada ikan, seperti M. morganii, R. planticola dan E. aerogenes (Björnsdóttir-Butler et al., 2010; Bjornsdottir, 2009; Emborg \& Dalgaard, 2008). Untuk melengkapi informasi yang telah tersedia terkait keberadaan $\mathrm{BPH}$ pada produk perikanan di Indonesia, terutama untuk produk beku atau produk yang disimpan pada suhu dingin, diperlukan penelitian terkait isolasi $\mathrm{BPH}$ psikrofilik dengan suhu inkubasi yang sesuai $\left(15^{\circ} \mathrm{C}\right)$ (Torido et al., 2014).

Meskipun jumlah BPH yang secara alami terdapat pada ikan hanya sekitar $1 \%$ dari keseluruhan mikroflora yang ada pada permukaan ikan hidup (FAO $\& W H O, 2012)$, namun dengan adanya histidin bebas pada ikan-ikan tertentu seperti tuna, tongkol dan cakalang maka aktivitas bakteri ini dapat dimulai segera setelah ikan ditangkap. Dengan demikian, apabila suhu setelah penangkapan tidak dipertahankan pada suhu dingin, pertumbuhan bakteri dan pembentukan histamin akan terjadi dengan cepat bahkan sebelum ikan mengalami fase post-mortem (FAO \& WHO, 2012; Lehane \& Olley, 2000). Salah satu tahapan yang disarankan untuk mengurangi kemungkinan kontaminasi BPH ke dalam daging ikan adalah melalui penyiangan secara hati-hati segera setelah ikan ditangkap (Visciano et al., 2012).

\section{KESIMPULAN}

Jenis BPH prolifik yang paling umum ditemui pada produk TTC segar yang dijual di TPI dan beberapa pasar domestik di wilayah Jawa Barat, DKI Jakarta, dan Banten adalah $M$. morganii $(69,8 \%)$ dan $P$. damselae $(6,9 \%)$, keduanya merupakan $\mathrm{BPH}$ mesofilik dan ditemukan baik pada ikan tuna, tongkol maupun cakalang. Isolat mesofilik lain yang teridentifikasi dari sampel TTC berasal dari genus Klebsiella $(4,7 \%)$, Proteus $(4,7 \%)$, Raoultella $(4,7 \%)$, Shewanella $(2,3 \%)$ dan Vibrio $(6,9 \%)$. Keberadaan BPH prolifik pada sampel TTC yang diperoleh mengindikasikan bahwa potensi akumulasi histamin di produk akhir mungkin terjadi apabila penerapan rantai dingin selama distribusi, penanganan dan pengolahan tidak dilakukan dengan baik. Untuk mengetahui karakteristik BPH prolifik tersebut, diperlukan penelitian lebih lanjut terkait kemampuan isolat untuk beradaptasi dan menghasilkan histamin pada kondisi penanganan dan pengolahan produk perikanan yang berbeda-beda. Selain itu, diperlukan penelitian terkait isolasi BPH psikrofilik, untuk mendapatkan gambaran kontaminasi pada produk perikanan beku atau yang disimpan pada suhu rendah.

\section{UCAPAN TERIMA KASIH}

Penelitian ini didanai oleh Balai Besar Riset Pengolahan Produk dan Bioteknologi Kelautan dan Perikanan (BBRP2BKP) melalui DIPA Tahun Anggaran 2020 Nomor SP DIPA- 032.12.2.403835/2020. Ucapan terima kasih disampaikan kepada tim peneliti Keamanan Pangan BBRP2BKP yang telah membantu pengambilan sampel di lapangan, Wahyu Widianto dan Anggraeni Musvitawati yang telah membantu preparasi sampel di laboratorium.

\section{DAFTAR PUSTAKA}

Antara. (2020). Keracunan Ikan Tongkol, Tiga Orang Masih Dirawat. Jawapos. Retrieved from https:// 
www.jawapos.com/jpg-today/12/03/2020/keracunanikan-tongkol-tiga-orang-masih-dirawat/

Björnsdóttir-Butler, K., Bolton, G. E., Jaykus, L.-A., McClellan-Green, P. D., \& Green, D. P. (2010). Development of molecular-based methods for determination of high histamine producing bacteria in fish. International Journal of Food Microbiology, 139(3), 161-167. doi:10.1016/ j.ijfoodmicro.2010.03.017

Bjornsdottir-Butler, K., Bowers, J. C., \& Benner, R. A., Jr. (2015). Prevalence and characterization of high histamine-producing bacteria in Gulf of Mexico fish species. Journal of Food Protection, 78(7), 13351342. doi:10.4315/0362-028x.Jfp-15-012

Bjornsdottir-Butler, K., Jones, J. L., Benner, R., \& Burkhardt III, W. (2011). Development of a real-time PCR assay with an internal amplification control for detection of Gram-negative histamine-producing bacteria in fish. Food Microbiology, 28(3), 356-363. doi:10.1016/ j.fm.2010.06.013

Bjornsdottir, K. (2009). Detection and control of histamineproducing bacteria in fish. (Disertasi). North Carolina State University, Ann Arbor.

Bjornsdottir, K., Bolton, G. E., McClellan-Green, P. D., Jaykus, L. A., \& Green, D. P. (2009). Detection of Gramnegative histamine-producing bacteria in fish: a comparative study. Journal of Food Protection, 72(9), 1987-1991. doi:10.4315/0362-028X-72.9.1987

Chendaki, B. (2020). Polisi Usut Keracunan Ikan Tongkol BPNT Pemalang. Retrieved from https:// www.puskapik.com/10690/berita/polisi-usutkeracunan-ikan-tongkol-bpnt-pemalang/

Chiang, Y. C., Yang, C. Y., Li, C., Ho, Y. C., Lin, C. K., \& Tsen, H. Y. (2006). Identification of Bacillus spp., Escherichia coli, Salmonella spp., Staphylococcus spp. and Vibrio spp. with $16 \mathrm{~S}$ ribosomal DNA-based oligonucleotide array hybridization. International Journal of Food Microbiology, 107(2), 131-137. doi:10.1016/j.ijfoodmicro.2005.04.028

Cox, K. L., Devanarayan, V., Kriauciunas, A., Manetta, J., Montrose, C., \& Sittampalam, S. (2004). Immunoassay Methods. In G. S. Sittampalam, N. P. Coussens, H. Nelson, M. Arkin, D. Auld, C. Austin, B. Bejcek, M. Glicksman, J. Inglese, P. W. Iversen, Z. Li, J. McGee, O. McManus, L. Minor, A. Napper, J. M. Peltier, T. Riss, J. O. Joseph Trask, \& J. Weidner (Eds.), Assay Guidance Manual (Internet). Bethesda, Maryland: Eli Lilly \& Company and the National Center for Advancing Translational Sciences.

Dalgaard, P., Madsen, H. L., Samieian, N., \& Emborg, J. (2006). Biogenic amine formation and microbial spoilage in chilled garfish (Belone belone belone) effect of modified atmosphere packaging and previous frozen storage. Journal of Applied Microbiology, 101(1), 80-95. doi:10.1111/j.13652672.2006.02905.x

Emborg, J., \& Dalgaard, P. (2008). Modelling the effect of temperature, carbon dioxide, water activity and $\mathrm{pH}$ on growth and histamine formation by Morganella psychrotolerans. International Journal of Food
Microbiology, 128(2), 226-233. doi:10.1016/ j.ijfoodmicro.2008.08.016

Emborg, J., Dalgaard, P., Kjølby, A., Sørensen, N. D., \& Larsen, I. K. (2008). Results of biogenic amine concentrations and microflora in seafood causing histamine fish poisoning (HFP) (3.4.2 - 2008). http:// seafoodplus.org/project/images/seafoodplus_report _report_3.4.2_-_jette_emborg_et_al.pdf

Fatuni, Y. S., Suwandi, R., \& Jacoeb, A. M. (2014). Identifikasi kadar histamin dan bakteri pembentuk histamin dari pindang badeng tongkol. Jurnal Pengolahan Hasil Perikanan Indonesia, 17(2), 112118.

Fletcher, G. C., Summers, G., Winchester, R. V., \& Wong, R. J. (1995). Histamine and Histidine in New Zealand Marine Fish and Shellfish Species, Particularly Kahawai (Arripis trutta). Journal of Aquatic Food Product Technology, 4(2), 53-74. doi:10.1300/ J030v04n02_04

Food and Agriculture Organization of the United Nations, \& World Health Organization (FAO \& WHO). (2012). Public health risks of histamine and other biogenic amines from fish and fishery products. Rome: FAO and $\mathrm{WHO}$.

Gardini, F., Özogul, Y., Suzzi, G., Tabanelli, G., \& Özogul, F. (2016). Technological Factors Affecting Biogenic Amine Content in Foods: A Review. Frontiers in Microbiology, 7, 1218-1218. doi:10.3389/ fmicb.2016.01218

Hwang, C. C., Tseng, P. H., Lee, Y. C., Kung, H. F., Huang, C. Y., Chen, H. C., \& Tsai, Y. H. (2019). Determination of histamine in Japanese Spanish Mackerel (Scomberomorus niphonius) meat implicated in a foodborne poisoning. Journal of Food Protection, 82(10), 1643-1649. doi:10.4315/0362-028x.Jfp-19111

Indriati, N., Rispayeni, \& Heruwati, E. S. (2006). Studi bakteri pembentuk histamin pada ikan kembung peda selama proses pengolahan]. Jurnal Pascapanen dan Bioteknologi Kelautan dan Perikanan, 1(2), 117-122. doi:10.15578/ jpbkp.v1i2.394

International Commission on Microbiological Specifications for Foods (ICMSF). (2005). Microbiology of Foods 6: Microbial Ecology of Food Commodities (2nd ed.). New York, USA: Kluwer Academic/Plenum Publishers.

Kanki, M., Yoda, T., Tsukamoto, T., \& Baba, E. (2007). Histidine decarboxylases and their role in accumulation of histamine in tuna and dried saury. Applied and Environmental Microbiology, 73(5), 14671473. doi:10.1128/aem.01907-06

Kementerian Kelautan dan Perikanan. (2016). Laporan Kinerja Kementerian Kelautan dan Perikanan 2016. Jakarta.

Kim, S., Field, K., Morrissey, M., Price, R., Wei, C., \& An, H. (2001). Source and identification of histamineproducing bacteria from fresh and temperatureabused albacore. Journal of Food Protection, 64(7), 1035-1044. doi:10.4315/0362-028X-64.7.1035 
Kim, S. H. (2001). Identification of bacteria crucial to histamine formation and monitoring their occurence and histamine accumulation in scombroid fish. Disertasi. Oregon State University.

Kimura, B., Konagaya, Y., \& Fujii, T. (2001). Histamine formation by Tetragenococcus muriaticus, a halophilic lactic acid bacterium isolated from fish sauce. International Journal of Food Microbiology, 70(1), 71-77. doi:10.1016/S0168-1605(01)00514-1

Klausen, N. K., \& Huss, H. H. (1987). Growth and histamine production by Morganella morganii under various temperature conditions. International Journal of Food Microbiology, 5(2), 147-156. doi:10.1016/ 0168-1605(87)90032-8

Lee, Y. C., Huang, T. C., Lin, C. S., Lin, C. M., \& Tsai, Y. H. (2012). Determination of histamine and histamineforming bacteria in Striped marlin fillets (Tetrapturus audax) implicated in a food-borne poisoning. Toxicon, 60(2), 161-162. doi:10.1016/j.toxicon.2012.04.133

Lehane, L., \& Olley, J. (2000). Histamine fish poisoning revisited. International Journal of Food Microbiology, 58(1-2), 1-37. doi:10.1016/S0168-1605(00)00296-8

Niven, C. F., Jeffrey, M. B., \& Corlett, D. A. (1981). Differential plating medium for quantitative detection of histamine producing bacteria. Applied and Environmental Microbiology, 41(1), 321-322.

Nucleotide. (1988). Bethesda (MD): National Library of Medicine (US), National Center for Biotechnology Information. Internet. Available from: https:// www.ncbi.nlm.nih.gov/nucleotide

Nurilmala, M., Saputri, N. N., Abdullah, A., Nurjanah, N., Yusfiandayani, R., \& Sondita, M. F. A. (2020). Detection of histamine-producing bacteria on tuna species using histidine decarboxylase (hdc) and 16S rRNA. Squalen Bulletin of Marine and Fisheries Postharvest and Biotechnology, 15(30), 131-139. doi:http:// dx.doi.org/10.15578/squalen.v15i3.445

Omura, Y., Price, R. J., \& Olcott, H. S. (1978). Histamine - forming bacteria isolated from spoiled skipjack tuna and jack mackerel. Journal of Food Science, 43(6), 1779-1781. doi:10.1111/j.1365-2621.1978.tb07412.x

Pusat Data Statistik dan Informasi KKP (PUSDATIN KKP). (2018). Kelautan dan Perikanan dalam Angka tahun 2018. Jakarta.

Rachmawati, N. (2019). Assessing the risk of histamine from the Indonesian salted-boiled fish (pindang). (Disertasi). University of Tasmania, Hobart, Tasmania.

Raharjo, D. B. (2020). Puluhan Warga Batang Diduga Keracunan Ikan Tongkol Bantuan Kemensos. Retrieved from https://jateng.suara.com/read/2020/ 06/18/153943/puluhan-warga-batang-didugakeracunan-ikan-tongkol-bantuan-kemensos

Supriadi, B. (2020). Korban Keracunan Ikan Tongkol di Jember Bertambah Lagi, Kini Jadi 350 Orang [Victims of fish poisoning in Jember increased, now accounted for 350 people]. Kompas. https:// regional.kompas.com/read/2020/01/03/11472551/ korban-keracunan-ikan-tongkol-di-jemberbertambah-lagi-kini-jadi-350-orang
Suryono. (2020). Ratusan Orang di Pemalang Diduga Keracunan Ikan Tongkol. https://news.okezone.com/ $\mathrm{read} / 2020 / 07 / 21 / 519 / 2249499 /$ ratusan-orang-dipemalang-diduga-keracunan-ikan-tongkol

Takahashi, H., Kimura, B., Yoshikawa, M., \& Fujii, T. (2003). Cloning and sequencing of the histidine decarboxylase genes of gram-negative, histamineproducing bacteria and their application in detection and identification of these organisms in fish. Applied and Environmental Microbiology, 69(5), 2568-2579. doi:10.1128/aem.69.5.2568-2579.2003

Tamura, K., Stecher, G., Peterson, D., Filipski, A., \& Kumar, S. (2013). MEGA6: Molecular Evolutionary Genetics Analysis version 6.0. Molecular Biology and Evolution, 30(12), 2725-2729. doi:10.1093/molbev/ mst197

Taylor, S. L. (1986). Histamine food poisoning - Toxicology and clinical aspects. CRC Critical Reviews in Toxicology, 17(2), 91-128. doi:10.3109/ 10408448609023767

Torido, Y., Ohshima, C., Takahashi, H., Miya, S., Iwakawa, A., Kuda, T., \& Kimura, B. (2014). Distribution of psychrophilic and mesophilic histamine-producing bacteria in retailed fish in Japan. Food Control, 46(0), 338-342. doi:10.1016/j.foodcont.2014.05.045

Trevisani, M., Mancusi, R., Cecchini, M., Costanza, C., \& Prearo, M. (2017). Detection and characterization of histamine-producing strains of Photobacterium damselae subsp. damselae isolated from mullets. Veterinary sciences, 4(2), 31. doi:10.3390/ vetsci4020031

United States Department of Health Human Services, Food Drug Administration (FDA), \& Center for Food Safety Applied Nutrition (CFSAN). (2011). Fish and fishery products hazards and controls guidance (Fourth ed.). Gainsville: Florida Sea Grant.

Virgantari, F., Daryanto, A., Harianto, \& Kuntjoro, S. U. (2011). Dinamika konsumsi produk perikanan di indonesia. Ekologia: Jurnal IImiah IImu Dasar dan Lingkungan Hidup, 11(2), 22-30.

Visciano, P., Schirone, M., \& Paparella, A. (2020). An overview of histamine and other biogenic amines in fish and fish products. Foods, 9(12). doi:10.3390/ foods 9121795

Visciano, P., Schirone, M., Tofalo, R., \& Suzzi, G. (2012). Biogenic amines in raw and processed seafood. Frontiers in Microbiology, 3(188), 1-10. doi:10.3389/ fmicb.2012.00188

Visciano, P., Schirone, M., Tofalo, R., \& Suzzi, G. (2014). Histamine poisoning and control measures in fish and fishery products. Frontiers in Microbiology, 5, 500. doi:10.3389/fmicb.2014.00500

Wahyuni, S. (2011). Histamin Tuna (Thunnus sp) dan Identifikasi Bakteri Pembentuknya pada Kondisi Suhu Penyimpanan Standar. Skripsi. Institut Pertanian Bogor, Bogor.

Weisburg, W. G., Barns, S. M., Pelletier, D. A., \& Lane, D. J. (1991). 16S ribosomal DNA amplification for phylogenetic study. Journal of Bacteriology, 173(2), 697-703. doi:10.1128/jb.173.2.697-703.1991 
Widria, Y. (2018). Ekspor Tuna Cakalang Tongkol Indonesia 6 Tahun Terakhir (2012-2017), Kondisi dan Harapan. https://kkp.go.id/djpdspkp/artikel/2746ekspor-tuna-cakalang-tongkol-indonesia-6-tahunterakhir-2012-2017-kondisi-dan-harapan

Wodi, S. I. M. (2015). Profil protein larut air dan histamin serta identifikasi bakteri penghasil histidin dekarboksilase pada tuna mata besar (Thunnus obesus). Thesis. Institut Pertanian Bogor, Bogor.
Wuryandani, D., \& Meilani, H. (2011). Kebijakan pengelolaan sumber daya perikanan laut untuk menunjang ketahanan pangan di Indonesia. Jurnal Ekonomi \& Kebijakan Publik, 2(1), 395422.

Yoshinaga, D. H., \& Frank, H. A. (1982). Histamine producing bacteria in decomposing skipjack tuna (Katsuwonus pelamis). Applied and Environmental Microbiology, 44(2), 447-452. 